\title{
Pedagogical alignment for entrepreneurial development
}

\author{
Jing Zhang ${ }^{1,2}$ \\ Accepted: 22 September 2020 / Published online: 6 October 2020 \\ (c) Springer Nature Singapore Pte Ltd. 2020
}

\section{Background}

The challenges of the 4th Industrial Age have created a fundamental change which is starting a new chapter in human development. The relationship with technology now impacts significantly upon every aspect of life including work and has changed the demands placed upon each worker (Schwab 2016). For students and graduates, life has never been more uncertain. They need to be entrepreneurial in order to overcome new challenges, embrace constant changes and thrive in work and personal life.

The role of education, from primary to higher, is increasingly to prepare students for the workplace, for jobs and careers that do not yet exist, as well as build up their capacity to cope with uncertainty, ambiguity and risk. Education can be the key to supporting future generations to thrive through change. It is against this global background that this Special Issue is published to explore the theme of "pedagogical alignment". By exploring entrepreneurial development through a wide range of diverse examples, this Special Edition evidences the case for alignment as it explores entrepreneurial development through consideration of policy, school education, staff development and start-up.

\section{Concepts of enterprise and entrepreneurship education}

Stating pedagogical alignment as key to enterprise and entrepreneurship education at all levels and for all outcomes, first requires clarity of definition. Assumptions and poor definition have plagued the field, and even Aulet, who has taught entrepreneurship for over a decade at MIT, points out that "too many people treat entrepreneurship as a catch-all term or as a single-minded focus on billion-dollar 'unicorn' startups... At MIT, we believe entrepreneurship is about more than just startups" (2017: 1).

Jing Zhang

bczhangjing@163.com

1 Enterprise Evolution UK, Liverpool, UK

2 Beijing Vision Chang International Education and Culture Consultancy Company Ltd, Beijing, China 
Understanding the concepts relating to enterprise and entrepreneurship is fundamental to researching and understanding practice within entrepreneurship education. Although varied definitions have been proposed each drawing out different perspectives, it is now widely accepted that not every graduate will start up a business, but that they will all need entrepreneurial mindset to think and act like an entrepreneur. Increasing educational definitions now lean towards the broader terms related to mindset development as opposed to the more narrowly defined start-up perspectives.

In its guidance for higher education providers around enterprise and entrepreneurship education, the UK Quality Assurance Agency (QAA 2018) defines enterprise education as "the generation and application of ideas, which are set within practical situations during a project or undertaking. This is a generic concept that can be applied across all areas of education and professional life. It combines creativity, originality, initiative, idea generation, design thinking, adaptability and reflexivity with problem identification, problem solving, innovation, expression, communication and practical action" (2018, p. 7).

In the pivotal report EntreComp: The Entrepreneurship Competence Framework (Bacigalupo et al. 2016), entrepreneurship is acknowledged as a key competence, recognising that "entrepreneurship is when you act upon opportunities and ideas and transform them into value for others. The value that is created can be financial, cultural, or social (FEE-YE 2012)". It calls for learning to become entrepreneurial through creating value for others and, in doing so, states the need to equip students with entrepreneurial mindset so that they can cope with uncertainties and risks.

\section{Pedagogical alignment for entrepreneurial development}

By defining these terms in a broad educational sense, the need for pedagogical alignment for all entrepreneurial development is made. Appreciation that the critical elements of learning, teaching and assessment, as well as policy and environment, need to be aligned in order to be effective is seen here. Education as preparation for a complex and unknowable future can only be enhanced when the interaction of such elements aligns and creates a stable structure, irrespective as whether the outcomes and outputs can be known.

This can be seen firstly through the alignment of curriculum with the uncertainty and challenges that students will have to face in the future. Currently, COVID-19 pandemic presents a global challenge, shaping the pattern of individual lives and national industries. Among many other negative consequences, people lose their jobs, struggle to maintain living standards and witness the destruction of expected career opportunities and pathways. At the same time, the world has witnessed entrepreneurial people who have seen this not as a challenge, but an opportunity. For example, in the field of education, when face-to-face classroom teaching becomes impossible, online platforms such as ZOOM and Tencent are developed or improved to meet the new and emerging educational needs. It is not just new start-ups and research spinouts that society needs to address challenges. New product development and business expansion have required the competencies of the intrapreneur-the 
entrepreneurial employee (Lackéus et al. 2020) making it clear the need to develop transversal skills required by students for modern industry and at the same time preparing for continuous improvement to cope with the accelerating changes in the next 50 years. In this Special Edition, the push to support students underpins each of the featured articles and the need to appreciate and align programmes within the wider context is evident.

Secondly, within teaching strategy the approach of "constructive alignment" (Biggs 2003) supports desired learning outcomes. Learning outcomes are a set of skills, knowledge and competence that students will be able to demonstrate mastery upon completion of study. To define learning outcomes, teachers need to start from knowing their students, i.e. who they are, where they are, where they need to be, and what previous knowledge and skills they have, and use Bloom's (1956) Taxonomy to set the desired level of students' mastery. The rule is that outcomes have to be actionable, observable, and measurable (Baume 2009). An aligned teaching strategy is then set around learning outcomes, taking into consideration resources available, local context and constraints, and effective tools and techniques. Good teaching puts the student learning in the centre from traditional "guru"-based teaching style ("sage on the stage") to a more collaborative, student focused (facilitated) approach to teaching. In this Special Edition, such alignment is apparent within course design and curriculum development. Whether for school children or the education of staff, the principles of alignment are clear.

Thirdly, align assessment with learning outcomes. Assessment is a way for students to prove they are capable of mastery as defined in the learning outcomes. While traditional education uses assessment to check whether students have reached the required level of knowledge (feedback or summative assessment), which makes exams and tests appropriate, enterprise education uses assessment to build and develop students' enterprise skills and competencies. Teachers should provide students with context where they can demonstrate whether they are able to get things done. If they cannot prove that they are capable to reach the learning objectives, teachers will provide them with guidance for improvement (feed-forward or formative assessment). In enterprise education, the learning process is as important as, if not more important than, the result. Authentic, relevant and aligned assessment takes various forms, formal and informal, such as a presentation, a project plan, a journal, a report and even verbal conferencing. Assessment does not always have to be conducted by the teacher of the course, when peers, stakeholders and general public can also contribute valid and valuable feedback. However, it is important to note that the value of education is to help students develop and grow and thus the impact of enterprise education can be best demonstrated through recognition of the changes to students through their behaviour and mindset. This Special Edition shows assessment, whether formal or informal, as a mechanism for change and improvement. The articles showcased here provide examples of practice that show how assessing movement within the learning journey supports the learner.

Fourthly, align learning environment with learning outcomes. Learning does not always have to take place in classrooms or in traditional settings. Students find that authentic learning environments that more closely mirror the realities of entrepreneurial endeavours are conducive to their learning. The assumption 
that opportunities create value for others (Lackeus 2015) motivates learning and drives forth the conclusion that teachers should endeavour to provide students with authentic learning environment where the problem truly exists, human relations are real, content is true, process is real and results meet the needs of a particular audience. Appreciation of the learning environment, whether at national policy level or within the classroom, features within this Special Edition as a theme throughout each paper. Together with the importance of human connections, the approaches highlighted here all demonstrate how impact can be achieved through an appreciation of context.

Finally, the focus is upon a recognition of the need to align the educator's role with the learning objectives. The role of both agents within the process is key and as Professor Sally Brown (2015: 55) points out in her analogy that curriculum delivery is "not so much about content being delivered as a postman delivers a parcel, but more like the process by which a midwife delivers a baby". Brown outlines this as "Maieutics" in which the student (like a women in labour) can be supported, advised and offered interventions when things go wrong, but recognises that in fact only the student can bring forth learning in an active rather than a passive process. Through this analogy, Brown helps the appreciation that the educator is a key agent or actor within enterprise and entrepreneurship education. As teachers change their mindset and teaching methodology from teacher-centred teaching to student-centred learning, a significant difference can be made to their students. Enterprise educators need to be entrepreneurial themselves in order to nurture enterprising students. This Special Edition evidences the role of the educator through the case study and journey of each example. By providing a lens on a variety of aspects of enterprise and entrepreneurship education, each paper demonstrates the pivotal role of the educator.

\section{Selection of the five articles}

The five papers in this Special Issue have been carefully selected to demonstrate alignment from each of these perspectives. Alignment underpins their approach and supports their success.

Developing Entrepreneurial Education in National School Curricula: Lessons from North Macedonia and Wales will be of interest to those who wish to advance national policies and entrepreneurial educator development. North Macedonian and Welsh educationalists are frontiersmen in entrepreneurial education, and they are responding to calls from Europe (Bourgeois et al. 2016) for a systematic approach that covers different levels and demonstrates progression. Having recognised the need for children and young people to develop a range of "wider skills" perceived necessary for modern life and work, with the aim of making them more resilient and able to cope with today's and tomorrow's challenges, the Welsh Government was determined to integrate an entrepreneurial culture within curriculum and assessment arrangements in schools and made funding available to pilot training for teachers at all levels, from schools to universities and across all subject specialisms. Supported 
by the World Bank, North Macedonia introduced a compulsory and progressively evaluated Entrepreneurship and Innovation curriculum in 2016, following policy decisions made in 2014. Teacher training initiatives from Wales informed progress.

The CRADLE Teaching Methodology: Developing Foreign Language and Entrepreneurial Skills in Primary School Pupils provides an example where students' entrepreneurial mindset can be developed through project-based learning using a target foreign language. The EU-funded CRADLE project "(Creating Activity Designed Language Learning Environments for Entrepreneurship Education)" set out to develop a teaching methodology for generalist primary school teachers to foster both entrepreneurial and language learning skills for students aged 8 to 12 . The CRADLE methodology places students' curiosity and initiative at the centre of the learning process and uses cross-curricular, activity-based, exploratory teaching and learning approach, which results in students' self-efficacy and value creation.

Value Creation Programmes: Lessons from an Early Stage Implementation presents critical insights into the manner in which entrepreneurial learning can be facilitated through Venture Creation Programme (VCP) at the University of Worcester. In the processes of conducting this review, the authors find that good pedagogical design, in a VCP context, needs to focus on ensuring that academics promote constructive alignment between the curriculum that is "taught", the teaching methods used, the learning environment chosen and the assessment procedures adopted. Only by minimising inconsistencies which link these factors will students' experiences of venture creation be fully engaging, promoting more effective, experiential and entrepreneurial development.

Entrepreneurial Educators: Vital Enablers to Support the Education Sector to Reimagine and Respond to the Challenges of Covid-19 examines the experiences of the educator as a key actor in entrepreneurship education. Through interviewing ten highly efficacious entrepreneurial UK enterprise educators, Dr. Carol Langston proposes a conceptual model of the essence of entrepreneurship education educators' experiences which identifies shared values, multiple identities and innovative practices.

Developing the Enterprise Educators' Mindset to Change the Teaching Methodology: The Case of Creating Entrepreneurial Outcomes Programme (CEO) examines how international practice is contextualised in the Chinese education market. It presents the very first UK-China co-created educator training programme designed to address China's enterprise education needs by drawing upon the recent traditions of European and UK enterprise education practice. The objective of the CEO programme is to develop the educators' mindset and teaching methodology, which for many in China is a significant paradigm shift from traditional contentcentred teaching to student-centred learning. This co-created approach resulted in the development of a new user focused diagram (the CEO "Canvas") as the underpinning approach for the enterprise education curriculum design. 


\section{Conclusion}

Enterprise and entrepreneurship education is broader than venture creation. Latest developments in this field focus on mindset development and value creation, which can be achieved at all levels of schooling from schools, further education to higher education. Those who are engaged in enterprise education have to be entrepreneurial, understand the challenges their students will have to cope with in the future, constructively align curriculum, set authentic learning environment and offer student support to enable them to develop and grow. While enterprise educators play a crucial role in nurturing entrepreneurial students, national policy and senior management support must equally be aligned to safeguard the work being done throughout the educational pipeline.

\section{References}

Aulet, W. (2017). What I've Learned About Teaching Entrepreneurship", 7 April 2017 https://mediu m.com/@USASBE/bill-aulet-on-what-ive-learned-about-teaching-entrepreneurship-395117694e11 Published Extract taken from Aulet, W (2016) in Matthews, C Liguori, E (eds) (2016) Annals of entrepreneurship education and pedagogy-2016 annals in entrepreneurship education series. Publication Date: 2016 ISBN: 9781784719159 Extent: 456.

Bacigalupo, M., Kampylis, P., Punie, Y., \& Van den Brande, G. (2016). EntreComp: The entrepreneurship competence framework. Publication Office of the European Union; Luxembourg, EUR 27939 http://publications.jrc.ec.europa.eu/repository/bitstream/JRC101581/lfna27939enn.pdf.

Baume, D. (2009). Writing and using good learning outcomes, Leeds Met Press, ISBN 978-0-9560099-5-1

Biggs, J. B. (2003). Teaching for quality learning at university (2nd ed.). Buckingham: Open University Press/Society for Research into Higher Education.

Bloom, B. S. (1956). Taxonomy of educational objectives. The classification of educational goals. London: Longman.

Bourgeois, A., Balcon, M. R., Jari, M. (2016). Eurydice Entrepreneurship Education at School in Europe, Eurydice Report, Resource document. Resource document. European Commission.Education, Audiovisual and Culture Executive Agency, European Commission

Brown, S. (2015). Learning, teaching and assessment in higher education: Global perspectives. London: Palgrave-MacMillan.

FFE-YE (2012). Impact of entrepreneurship education in Denmark-2011. In Vestergard, L., Moberg, K., \& Jorgensen, C. (Eds) Odense The Danish Foundation for Entrepreneurship-Young Enterprise. Retrieved 30 June, 2020 from https://eacea.ec.europa.eu/nationalpolicies/eurydice/content/entre preneurship-education-school-europe_en.

Lackeus (2015). Entrepreneurship in education, what why when and how, entrepreneurship 360 background paper. Available http://www.oecd.org/cfe/leed/BGP_Entrepreneurship-in-Education.pdf.

Lackéus, M., Lundqvist, M., Williams Middleton, K., \& Inden, J. (2020). The entrepreneurial employee in public and private sector-What, Why, How. In Bacigalupo, M. (eds), EUR 30108 EN, Publications Office of the European Union, Luxembourg, 2020, ISBN 978-92-7616651-1 (online),978-92-76-16652-8 (print), https://doi.org/10.2760/460123 (online), https://doi. org/10.2760/265489 (print), JRC117661.

Quality Assurance Agency (2018) Enterprise and Entrepreneurship Education: Guidance for UK Higher Education Providers http://www.qaa.ac.uk/docs/qaas/enhancement-and-development/enterprise -and-entrpreneurship-education-2018.pdf?sfvrsn=15f1f981_.

Schwab, K. (2016). The Fourth Industrial Revolution. Crown Business. ISBN 978-1-5247-5886-8.

Publisher's Note Springer Nature remains neutral with regard to jurisdictional claims in published maps and institutional affiliations. 